\title{
Japanese and European Private International Law in Comparative Perspective
}

\author{
Ed. by Jürgen Basedow, Harald Baum and Yuko Nishitani
}

[Japanisches und Europäisches Internationales Privatrecht im Vergleich.]

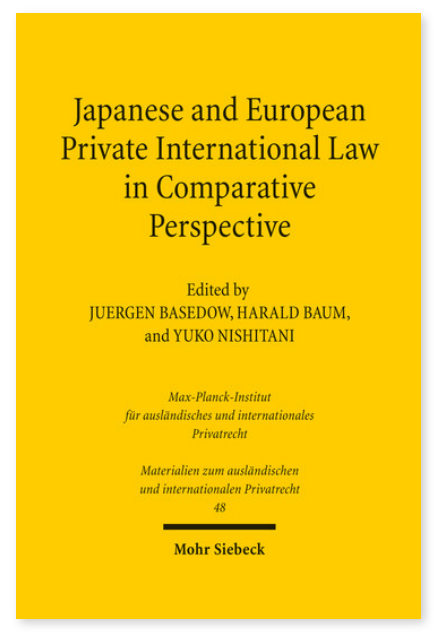

2008. XVIII, 434 Seiten. MatIPR 48

ISBN 978-3-16-151295-7

DOI 10.1628/978-3-16-151295-7

eBook PDF 114,00€
Veröffentlicht auf Englisch.

Am 1. Januar 2007 trat das neue japanische 'Gesetz über die allgemeinen Regeln über die Anwendung von Gesetzen (Rechtsanwendungsgesetz)' in Kraft und ersetzte das Statut von 1898. Auch in der Europäischen Union werden derzeit Anstrengungen unternommen, ein modernes Regime des Internationalen Privatrechts für die Mitgliedsstaaten zu schaffen. Dieser Band präsentiert die allererste verständliche Analyse des japanischen Internationalen Privatrechts, die in einer westlichen Sprache erhältlich ist, und kontrastiert sie mit den entsprechenden Entwicklungen auf europäischer Ebene. Die meisten der japanischen Beiträger sind Wissenschaftler, die am Gesetzesentwurf für das neue Gesetz mitgewirkt haben. Alle sind bekannte Experten in diesem Bereich. Viele europäische Experten für das Kollisionsrecht ergänzen den Band mit vergleichenden Studien und reflektieren damit die entsprechende Diskussion in der EU. Für ein besseres Verständnis wurden englische Übersetzungen der japanischen Gesetze angehängt.

Inhaltsübersicht

\section{General Introduction}

Jürgen Basedow: The Recent Development of the Conflict of Laws - Trevor C. Hartley: The Brussels Regulation and NonCommunity States - Masato Dogauchi: Historical Development of Japanese Private International Law - Hironori Wanami: Background and Outline of the Modernization of Japanese Private International Law

II. Contractual Obligations

Yuko Nishitani: Party Autonomy and Its Restrictions by Mandatory Rules in Japanese Private International Law - Catherine Kessedjian: Party Autonomy and Characteristic Performance in the Rome Convention and the Rome I Proposal - Fausto Pocar: Protection of Weaker Parties in the Rome Convention and the Rome I Proposal

III. Assignment of Receivables

Aki Kitazawa: Law Applicable to the Assignment of Receivables in Japan (Nihon ni okeru saiken jôto no junkyo-hô) - Eva-Maria Kieninger: General Principles on the Law Applicable to the Assignment of Receivables in Europe IV. International Company Law

Dai Yokomizo: International Company Law in Japan - Sylvaine Poillot-Peruzzetto: International Company Law in the ECJ Decisions - Daniel Zimmer: The Proposal of the Deutscher Rat für Internationales Privatrecht

V. Non-Contractual Obligations

Toshiyuki Kono: Critical and Comparative Analysis of the Rome II Regulation on Applicable Laws to Non-contractual Obligations and the New Private International Law in Japan - Thomas Kadner Graziano: General Principles of Private International Law of Tort in Europe - Marc Fallon: The Law Applicable to Specific Torts in Europe

VI. International Family Law

Yasuhiro Okuda: Divorce, Protection of Minors, and Child Abduction in Japan's Private International Law - Maarit JänteräJareborg: Jurisdiction and Applicable Law in Cross-Border Divorce Cases in Europe - Alegría Borrás: Protection of Minors and Child Abduction under the Hague Conventions and the Brussels II bis Regulation

VII. International Civil Procedure Law

Yoshihisa Hayakawa: International Adjudicative Jurisdiction in Japan - Dieter Martiny: Recognition and Enforcement of Foreign Judgments in Germany and Europe

Annex I

Major European Community Legislation in Private International Law Annex II

Japanese Legislation in Private International Law

Harald Baum Born 1952; study of law at the Universities of Hamburg and Freiburg; 1984 Ph.D.; 2004 Habilitation; Senior Research Fellow, Max Planck Institute for Comparative and International Private Law, Hamburg; Senior Lecturer at the University of Hamburg.

Jürgen Basedow (1949-2023)

1997-2017 Director em. of the Max Planck Institute for Comparative and International Private Law and Professor of Law, University of Hamburg.

Yuko Nishitani Born 1969; study of law at the Universities of Kyoto and Heidelberg; 1998 Ph.D.; 1997-2007 Associate Professor at Tohoku University in Sendai; since October 2007 Visiting Scholar, Paris.

Jetzt bestellen:

https://mohrsiebeck.com/buch/japanese-and-european-private-international-law-in-comparative-perspective9783161512957?no_cache=1

order@mohrsiebeck.com 
Telefon: +49 (0)7071-923-17

Telefax: +49 (0)7071-51104

Mohr Siebeck GmbH \& Co. KG

Postfach 2040

D-72010 Tübingen

info@mohrsiebeck.com

Mohr Siebeck

www.mohrsiebeck.com 